Available online on 15.01.2018 at http://ujpr.org
Universal Journal of Pharmaceutical Research
An International Peer Reviewed Journal
Open access to Pharmaceutical research
Commercial Share Alike 4.0 License which permits unrestricted non commercial use,
provided the original work is properly cited
Volume 2, Issue 6, 2017

\title{
BIODEGRADATION OF PARACETAMOL BY NATIVE FUNGAL SPECIES INHABITING WASTEWATER OF A PHARMACEUTICAL FACTORY IN SANA'A, YEMEN

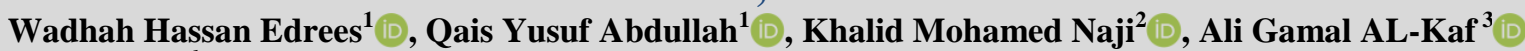 \\ ${ }^{1}$ Microbiology Division, Biology Department, Faculty of Science, Sana'a University, Yemen. \\ ${ }^{2}$ Chemistry Department, Faculty of Science, Sana'a University, Yemen. \\ ${ }^{3}$ Medicinal Chemistry Department, Faculty of Pharmacy, Sana'a University, Yemen.
}

\section{ABSTRACT}

Objectives: Paracetamol has emerged as an important environmental contaminant due to its extensive use. The purpose of this work was toisolate, identify, and characterize fungal species able to degrade paracetamol from pharmaceutical wastewater effluent at Sana'a City, Yemen.

Methods: The fungi were isolated and purified from wastewater samples using enrichment and selective media. The isolated fungi were identified according to phenotypic characterization. Two species of isolated fungi were able to utilize the paracetamol as the sole of carbon and energy sources. These fungi were designated as F1 and F2 and identified as Aspergillus niger and Fusarium oxysporium, respectively. Optimum temperature and $\mathrm{pH}$ for growth of both species were $25^{\circ} \mathrm{C}$ and 6.0 , respectively. Also, the biodegradation of paracetamol was influenced by glucose concentration.

Results: F1 and F2 were able to degrade $35.7 \%$ and $26.1 \%$ of 1000 and $2000 \mathrm{mg} / \mathrm{l}$, respectively, paracetamol in 60 days. This is the first report on the ability of Aspergillus niger and Fusarium oxysporium to degrade paracetamol.

Conclusion: The reported findings highlight the potential use of the isolated microorganisms for treatment of paracetamolcontaminated wastewater.

Keywords: Biodegradation, fungi, isolation, optimization, Paracetamol.

Article Info: Received 4 November 2017; Revised 3 December; Accepted 31 December, Available online 15 January 2018

口15: $\square$ Cite this article-

Edrees WH, Abdullah QY, Naji KM, AL-Kaf AG. Biodegradation of paracetamol by native fungal species inhabiting wastewater of a pharmaceutical factory in Sana'a, Yemen. Universal Journal of Pharmaceutical Research 2017; 2(6): 32-37.

DOI: http://doi.org/10.22270/ujpr.v2i6.R7

Address for Correspondence

Dr. Wadhah Hassan Edrees, Microbiology Division, Biology Department, Faculty of Science, Sana'a University, Yemen. Mobile-00967-771673230, E-mail: edress2020@gmail.com

\section{INTRODUCTION}

Paracetamol or acetaminophen is a common analgesic and an anti-inflammatory widely used as a nonprescription drug that is sold as over-the-counter (OTC) worldwide ${ }^{1}$. The paracetamol consumption has increased throughout the world in the past decades in England, it was one of the top three drugs prescribed, while in the USA, it was one of the top 200 prescriptions $^{2,3}$. In Kuwait, it ranked as the second most-common prescription drug throughout $2008^{4}$. In Yemen, it was ranked first among the top ten drugs manufactured by local industries, and one of the top ten imported drugs 5 . Paracetamol is one of the most common detected drug in the aquatic environment; at $0.298 \mu \mathrm{g} / \mathrm{l}$ in drinking water ${ }^{6}, 6.5 \mu \mathrm{g} / 1$ in ground water ${ }^{7}$, $15.7 \mu \mathrm{g} / \mathrm{l}$ in surface water ${ }^{8}, 1.367 \mathrm{mg} / \mathrm{l}$ in wastewater ${ }^{9}$, and $0.246 \mathrm{mg} / \mathrm{l}$ in sewage water ${ }^{10}$. Therefore, the potential risk and effects of paracetamol on the environment and human health have become of concern $^{11}$. Previous efforts on the removal of paracetamol from wastewater mainly focused on chemical methods including oxidation processes such as ozonation and $\mathrm{H}_{2} \mathrm{O}_{2} / \mathrm{UV}$ oxidation ${ }^{12}$ and $\mathrm{TiO}_{2}$ photocatalysis $^{13}$. The major drawbacks of using these methods are the high operational and energy costs, as well as the generation of secondary pollutants due to the use of excessive chemicals ${ }^{14}$. Biodegradation of organic substances is being considered as an environmentally friendly and low-cost option. This process currently receives considerable attention due to its efficiency and ability to degrade different pollutants via the catalytic activity of microbial organisms. In the past decades, biodegradation investigations of 
paracetamol have largely focused on the use of different bacteria ${ }^{4}$. The use of fungi as a method of bioremediation provides an alternative to the cleanup of environmental pollutants. Fungi have recently received significant attention for their bioremediation potential which is attributed to the enzymes they produce $^{15}$. To date, few studies have investigated the potential degradation of paracetamol by fungi. In this study, the isolation, identification, and characterization of new paracetamol degrading fungi from paracetamolcontaminated waste water was performed. The isolated fungi species were further investigated for optimization of growth and paracetamol-degradation parameters. The wastewater was from the Yemen Drug Company for Industrial and Commercial (YEDCO) situated at Sana'a City, Yemen. Since 1982, to data, this company has been generating wastewater containing high concentrations of paracetamol. Therefore, indigenous microbes that were capable of treating various liquid toxic wastes might be present at this site.

\section{MATERIALS AND METHODS}

\section{Chemicals and cultivation medium}

Chemicals used were paracetamol ultrafine powder (Anqiu Lu'an Pharmaceutical Co. LTD., Chain), and acetonitrile and methanol (Merck, USA). All pharmaceutical standards were of high-purity grade (>99\%). The applied basal mineral salts medium (BMSM) consisted of $3.0 \mathrm{~g} \quad \mathrm{NaNO}_{3}, \quad 0.5 \mathrm{~g}$ $\mathrm{MgSO}_{4} .7 \mathrm{H}_{2} \mathrm{O}, 0.5 \mathrm{~g} \mathrm{KCl}, 3.5 \mathrm{~g} \mathrm{KH}_{2} \mathrm{PO}_{4}$, and $0.5 \mathrm{~g}$ of $\mathrm{Na}_{2} \mathrm{HPO}_{4}$ per liter of distilled water. The $\mathrm{pH}$ was adjusted between 5.8 to 6.0 and the medium was sterilized at $121^{\circ} \mathrm{C}$ for $20 \mathrm{~min}^{16}$. Paracetamol was added as the sole source of carbon and energy at different concentrations, then the medium was sterilized by filtration $(0.22 \mu \mathrm{m})$. For preparing solid media, $1.5 \%$ w/v agar (Fluka, Bio Chemika, Switzerland) was used.

\section{Sampling, isolation, and purification of fungi}

Wastewater samples were collected from the effluent generated by YEDCO factory situated in Sana'a City, Yemen. One milliliter of each sample was transferred to a bottle containing $90 \mathrm{ml}$ of Sabouraud dextrose broth (SDB) media. Each bottle was incubated at $25^{\circ} \mathrm{C}$ for 5 days. Five milliliters of SDB media were inoculated into BMSM containing $250 \mathrm{mg} / \mathrm{l}$ of paracetamol and $0.8 \mathrm{~g} / \mathrm{l}$ glucose (i.e. enriched medium), and the medium was incubated at $25^{\circ} \mathrm{C}$ for 14 days ${ }^{16,17}$. Subsequently, $1 \mathrm{ml}$ of enriched BMSM was transferred to BMSM agar containing $250 \mathrm{mg} / \mathrm{l}$ of paracetamol, and the medium was incubated at $25^{\circ} \mathrm{C}$ for 15 days. Plates showing growth were subjected to subculturing on Sabouraud dextrose agar (SDA) to obtain pure colonies. Next colonies were transferred several times on BMSM agar containing paracetamol, and finally confirmed to be pure by growth on SDA. Pure colonies were tested for growth on a range of paracetamol concentrations (250-2000 mg/l) in BMSM agar ${ }^{16,17}$.

\section{Identification of isolated fungi}

The isolated fungi were characterized by taxonomic studies and identified as described by Moubasher ${ }^{18}$. Identification of the isolated fungi was performed by macroscopic examination of colony morphology on pure cultures, and by microscopic examination with Lactophenol cotton blue stain ${ }^{18}$.

\section{Optimization study}

Parameters such as $\mathrm{pH}$, temperature, carbon source, and contact time, were optimized to enable the isolated strains to utilize paracetamol effectively as a carbon and energy source.

Effect of temperature and $\mathrm{pH}$ on paracetamol biodegradation

The effects of the temperature and $\mathrm{pH}$ on paracetamol biodegradation were evaluated individually for each isolated fungi on BMSM $(90 \mathrm{ml})$ containing $1000 \mathrm{mg} / \mathrm{l}$ paracetamol. The isolated fungi were cultured individually on the BMSM and incubated at different temperatures $\left(15,20,25,30\right.$, and $\left.35^{\circ} \mathrm{C}\right)$ for 30 days. The optimum $\mathrm{pH}$ for paracetamol biodegradation was determined using BMSM having different $\mathrm{pH}$ levels (4, $4.5,5,5.5,6,6.5,7,7.5$, and 8) that were incubated at $25^{\circ} \mathrm{C}$ for 30 days. The $\mathrm{pH}$ values were adjusted using 1 $\mathrm{N} \mathrm{NaOH}$ and $1 \mathrm{~N} \mathrm{HCl}$. Samples were withdrawn at regular intervals and centrifuged at $12000 \mathrm{rpm}$ for 15 min. The supernatant was collected in separate clean test tubes and analyzed for measuring the residual paracetamol concentration ${ }^{17,19}$.

Effect of glucose concentration on the paracetamol biodegradation

The effect of glucose on paracetamol biodegradation was evaluated utilizing different glucose concentrations $(0,1,2,3,4$, and $5 \mathrm{mg} / \mathrm{l})$. Each concentration of glucose was added separately to BMSM $(90 \mathrm{ml})$ containing-paracetamol $(1000 \mathrm{mg} / \mathrm{l})$, that was inoculated by each fungal species, and that was incubated at $25^{\circ} \mathrm{C}$ for 60 days. Sampling was done at regular time ${ }^{20}$.

Effect of incubation period on the different concentration of paracetamol

The effect of incubation period on biodegradation of different concentration of paracetamol was carried out in bottles containing $90 \mathrm{ml}$ of BMSM. Each fungal isolate was cultured individually on BMSM containing different concentrations of paracetamol $(250-2000$ $\mathrm{mg} / \mathrm{l}$ ) and incubated at $25^{\circ} \mathrm{C}$ at different incubation periods such as $10,20,30,40,50$ and 60 days. After each designated time, the medium was analyzed for residual paracetamol levels.

\section{Chemical analysis methods}

Three hundred milligrams of paracetamol working standard was weighed and dissolved in $70 \mathrm{ml}$ of methanol in a $100 \mathrm{ml}$ volumetric flask. Total $5 \mathrm{ml}$ of solution was transferred to a $100 \mathrm{ml}$ volumetric flask containing $47 \mathrm{ml}$ of methanol and $53 \mathrm{ml}$ of purified water and mixed well. Next, $10 \mathrm{ml}$ of this solution was filtered through a $0.22 \mu \mathrm{m}$ nylon membrane filter before use in other experiments ${ }^{21}$.

\section{Paracetamol level determination}

The residual concentration of paracetamol was determined using HPLC (Perkin Elmer, USA). The mobile phase with a flow rate of $1.0 \mathrm{ml} / \mathrm{min}$ consisted of acetonitrile:water $(47: 53 \mathrm{v} / \mathrm{v})$. The separation was performed at $30^{\circ} \mathrm{C}$ using a $\mathrm{RP}-8$ column $(5 \mu \mathrm{m}$, $4.6 \times 250 \mathrm{~mm})$. The injection volume was $20 \mu \mathrm{m}$, 
retention time was $5 \mathrm{~min}$, and detection wavelength was fixed at $275 \mathrm{~nm}^{21}$

\section{RESULTS}

\section{Identification and characterization of isolates}

The YEDCO factory wastewater was chosen as the source for isolating microorganisms in this project. Two fungal species capable of degrading paracetamol at different concentration were isolated from the wastewater samples and designated as F1 and F2, which were later identified as Aspergillus niger and Fusarium oxysporium, respectively, according to morphological characterization. Figure 1 shows color change on the BMSM agar containing paracetamol by F1 and F2. Figure 2 shows the change in color of BMSM broth after several days of incubation indicating the formation of paracetamol degradation products.
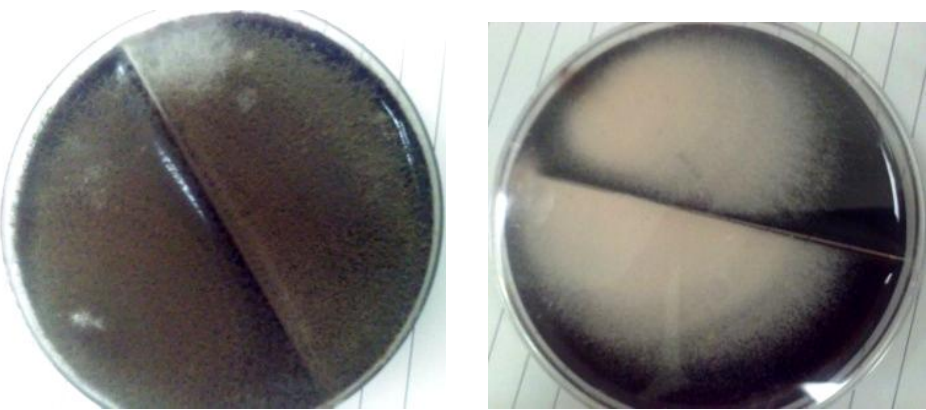

Figure 1: F1 and F2 species growth on BMSM agar containing paracetamol.

\section{Optimization study}

Effect of temperature and $\mathrm{pH}$ on paracetamol biodegradation

The effects of temperature and $\mathrm{pH}$ on the biodegradation rate of paracetamol $(1000 \mathrm{mg} / \mathrm{l})$ were determined after 30 days. The temperature range selected for the biodegradation of paracetamol was 15 to $35^{\circ} \mathrm{C}$. Maximum biodegradation of paracetamol was $30.6 \%$ and $51.4 \%$ observed at $25^{\circ} \mathrm{C}$ by $\mathrm{F} 1$ and $\mathrm{F} 2$, respectively, after 30 days. A decrease in paracetamol degradation was reported at temperatures greater than $30^{\circ} \mathrm{C}$ or less than $20^{\circ} \mathrm{C}$ for both $\mathrm{F} 1$ and $\mathrm{F} 2$ (Figure 3 ).

The effect of $\mathrm{pH}$ on paracetamol degradation was investigated at various initial $\mathrm{pH}$ values (4.0-8.0). The optimum $\mathrm{pH}$ for paracetamol degradation was 6.0 for both species.

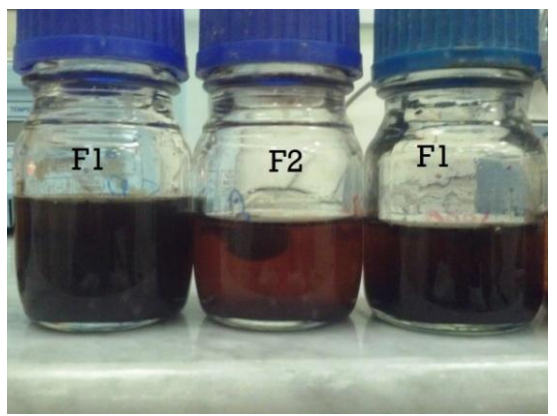

Figure 2: Growth of F1 and F2 in BMSM broth.

F1 and F2 degraded $30.6 \%$ and $51.4 \%$ of $1000 \mathrm{mg} / \mathrm{l}$ paracetamol within 30 days, respectively. However, degradation efficiency was relatively high across a $\mathrm{pH}$ range of 5.5-6.5. The degradation rate decreased at a $\mathrm{pH}$ greater than 7.0 or smaller than 5.0 (Figure 4).

Effects of incubation period on biodegradation of different concentrations of paracetamol

The paracetamol biodegradation by $\mathrm{F} 1$ and $\mathrm{F} 2$ was evaluated at different concentrations of paracetamol at different incubation periods. F1 degraded $45.06 \%$ and $35.7 \%$ of $750 \mathrm{mg} / \mathrm{l}$ and $1000 \mathrm{mg} / \mathrm{l}$, respectively, of paracetamol in 60 days. Also, $100 \%$ and $52.4 \%$ of paracetamol were degraded at an initial concentration of 250 and $500 \mathrm{mg} / \mathrm{l}$, respectively, at 50 days (Figure 5 ). F2 degraded $41 \%$ and $26.1 \%$ of paracetamol in 60 days at an initial concentration of $1500 \mathrm{mg} / \mathrm{l}$ and 2000 $\mathrm{mg} / \mathrm{l}$, respectively. At 750 and $1000 \mathrm{mg} / \mathrm{l}, 86.93 \%$ and $68.9 \%$ of paracetamol were degraded in 60 days, respectively, (Figure 6).

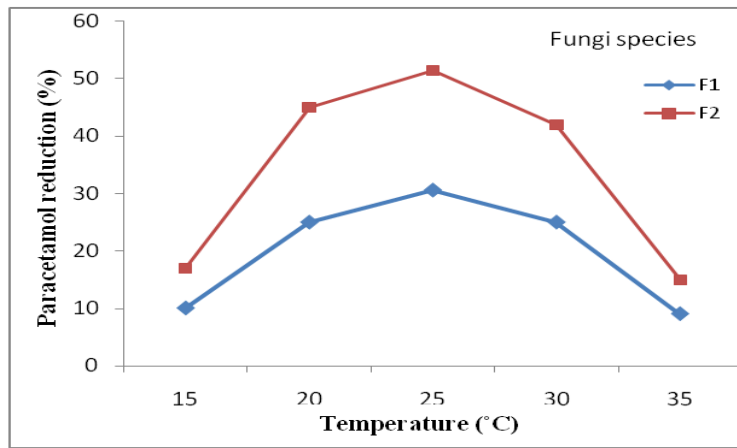

Figure 3: Effect of different temperatures on paracetamol biodegradation.

Effect of glucose on paracetamol biodegradation

The effects of different concentrations of glucose on paracetamol biodegradation were investigated for F1 and F2 on BMSM containing-paracetamol (1000 mg/l) at $25^{\circ} \mathrm{C}$ for 60 days. Paracetamol biodegradation increased with increasing glucose concentration for both fungal species. At $5 \mathrm{mg} / \mathrm{l}$ of glucose, $100 \%$ and $91.3 \%$ of $1000 \mathrm{mg} / \mathrm{l}$ paracetamol were degraded by F1 and F2 species, respectively, after 60 days (Figure 7 and Figure 8).

\section{DISCUSSION}

Microorganisms play a significant role in biological decomposition of hazardous compounds present in the environment. Several fungi are known to degrade persistent pollutants. The results of the present study 
demonstrated that a site contaminated with pharmaceutical wastewater effluent containing paracetamol is rich with variety microorganisms able to utilize paracetamol as a sole source of carbon and energy. Two fungal species signed as F1 and F2 were isolated from the waste water effluent contaminated site and were identified as Aspergillus niger and Fusarium oxysporium, respectively. Similarly, Mendonça et al., ${ }^{22}$ isolated $F$. flocciferum from an industrial effluent containing phenol. Also, it was isolated Penicillium sp. from a paracetamolcontaminated site ${ }^{16}$.

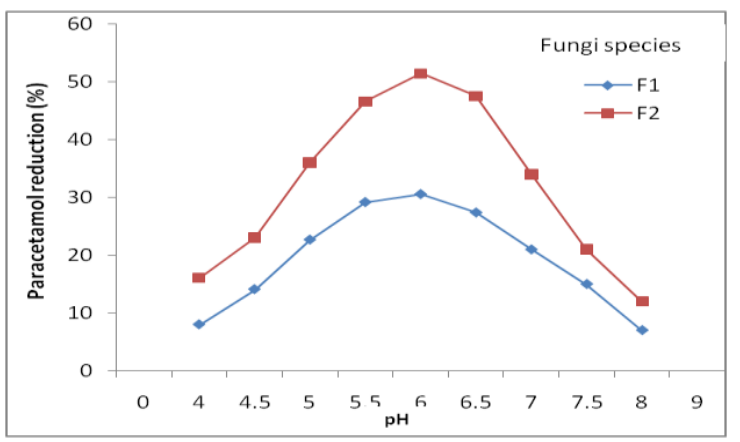

Figure 4: Effect of pH on paracetamol biodegradation.

Fungi are applied in degradation of persistent organic contaminants due to their general oxidative enzymatic system, that includes ligninolytic extracellular enzymes as laccase and peroxidases, as well as intracellular enzymes as the cytochrome P450 system $^{23,24}$. Kamaraj et al., ${ }^{25}$ isolated Aspergillus sp. from a tannery effluent as a bisphenol A degrader. Also, it was isolated Penicillium sp. CHY-2 from Antarctic soil that is able to use some aliphatic and aromatic hydrocarbons as a sole source of carbon and energy ${ }^{26}$. Raaman et al., ${ }^{27}$ isolated an Aspergillus sp. from the polythene polluted sites around Chennai.

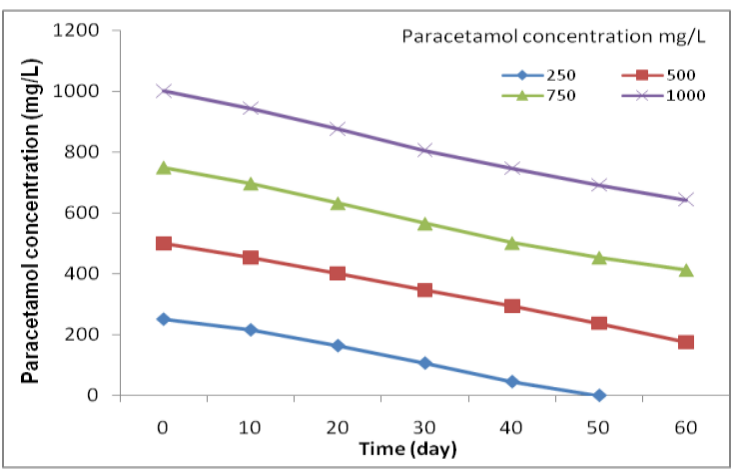

Figure 5: Paracetamol degradation curve by F1.

Temperature plays a vital role in biodegradation and gives an understanding to degradation pathways for paracetamol. Activities of the enzymes produced by the fungi are influenced directly by temperature. In this study, the optimum temperature for paracetamol biodegradation was $25^{\circ} \mathrm{C}$ for both isolated fungi. Increasing or decreasing temperature from the optimum $25^{\circ} \mathrm{C}$ levels decreased rate of paracetamol biodegradation. An important abiotic factor affecting microbial metabolism is $\mathrm{pH}$. The biodegradation of paracetamol was affected by the initial $\mathrm{pH}$ of the culture medium. The optimum $\mathrm{pH}$ for paracetamol degradation was 6.0 for both fungal species. This result is consistent with that by Marinho et al., ${ }^{28}$ who reported that the optimum $\mathrm{pH}$ for atrazine degradation by $A$. niger was 5 .

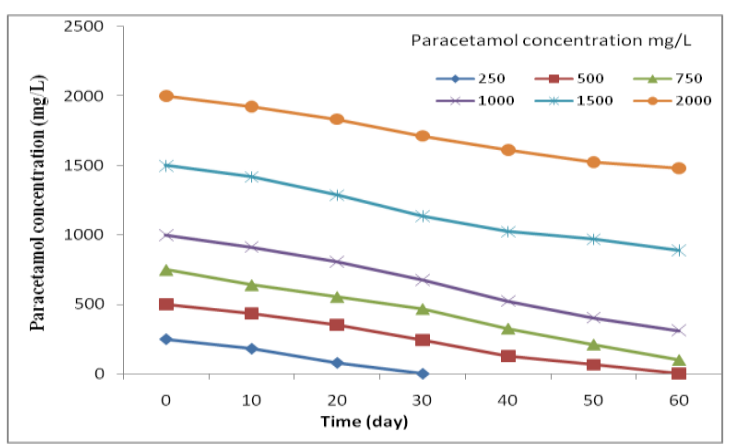

Figure 6: Paracetamol degradation curve by F2.

Also, Govarthanan et al., ${ }^{26}$ recorded that decane degradation by Penicillium sp. CHY-2 was high (at $81 \%$ ) at $\mathrm{pH} 6.0$ and $25^{\circ} \mathrm{C}$ after 28 days. Another study by Yemendzhiev et al., ${ }^{29}$ reported that the maximum degradation of a phenol and cresol mixture by Aspergillus awamori was at $\mathrm{pH}$ of 5.5 and $25^{\circ} \mathrm{C}$. In contrast, to these results, Kamaraj et al., ${ }^{25}$ found that the optimum $\mathrm{pH}$ for bisphenol A removal by Aspergillus sp. was at $\mathrm{pH} 9.0$. The carbon source of the growth medium is an important factor for the growth and metabolism of a microorganism. Selection of an ideal and economical carbon source accelerates the growth of the fungus as well as the biodegradation process $^{30}$. Glucose is a rapidly metabolized substrate by fungi. Therefore, fungi appear to have a higher affinity to glucose than other carbon sources ${ }^{28}$.

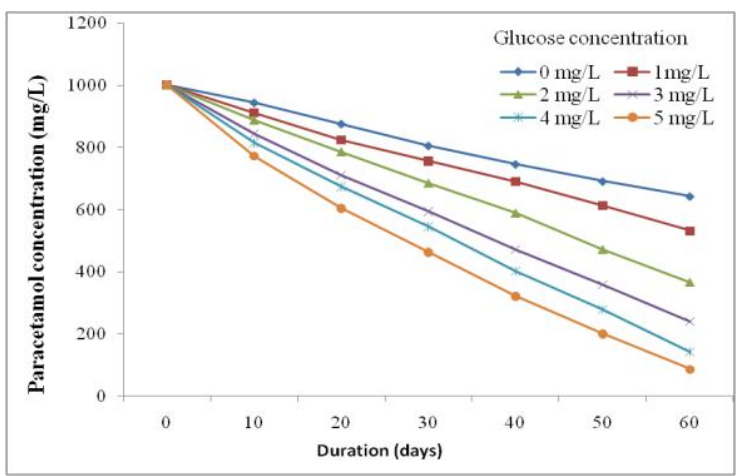

Figure 7: Effect of glucose supplementation to medium on paracetamol biodegradation by $\mathrm{F} 1$.

In this study, paracetamol biodegradation was enhanced by increasing glucose concentration in the culture medium. Similarly, it was reported that the benzo(a) pyrene degradation by Fusariumsolani was approximately $9 \%$ and $50 \%$ in presence of $1 \mathrm{~g} / \mathrm{l}$ and 10 $\mathrm{g} / 1$ of glucose, respectively ${ }^{31}$. It was evaluated the effect of glucose on the removal of methyl parathion by A. niger AN400, and found that the presence of 0.5 $\mathrm{mg} / \mathrm{l}$ glucose increased the rate of removal of methyl parathion ${ }^{28}$. A study by Govarthanan et al., ${ }^{26}$ indicated that the addition of $5 \mathrm{~g} / \mathrm{l}$ of glucose enhanced decane 
degradation by about 1.8 -fold at $20^{\circ} \mathrm{C}$, and reported that glucose is the most suitable carbon source for the growth of Penicillium sp. CHY-2. Also, Marinho et al. ${ }^{32}$ reported degradation of atrazine $(30 \mathrm{mg} / \mathrm{l})$ by $A$. niger AN400 in presence of glucose ${ }^{32}$. Fungi are used to degrade a wide variety of materials and compounds, a process known as mycodegradation ${ }^{33}$. In this work, the ability of the isolated fungal species was evaluated at different concentrations of paracetamol with different incubation periods. F1 was able to degrade $100 \%$ of $500 \mathrm{mg} / \mathrm{l}$ of paracetamol at 50 days and $35.7 \%$ of $1000 \mathrm{mg} / \mathrm{l}$ in 60 days. Also, F2 degraded $86.93 \%$ and $26.10 \%$ of 750 and $2000 \mathrm{mg} / \mathrm{l}$, respectively, of paracetamol within 60 days. A similar study by Hart and Orr $^{16}$ first reported the degradation of paracetamol by an isolated fungal species identified as a Penicillium sp. This species possessed the ability to utilize paracetamol as the sole carbon source for growth. Also, Cruz-Morató et al., ${ }^{34}$ experimented with the treatment of paracetamol using a Trametes versicolor in a batch fluidized bed bioreactor containing a concentration of paracetamol between $109.3 \mu \mathrm{g} / \mathrm{l}-114.4 \mu \mathrm{g} / \mathrm{l}$. Paracetamol was completely removed by $T$. versicolor after 8 days.

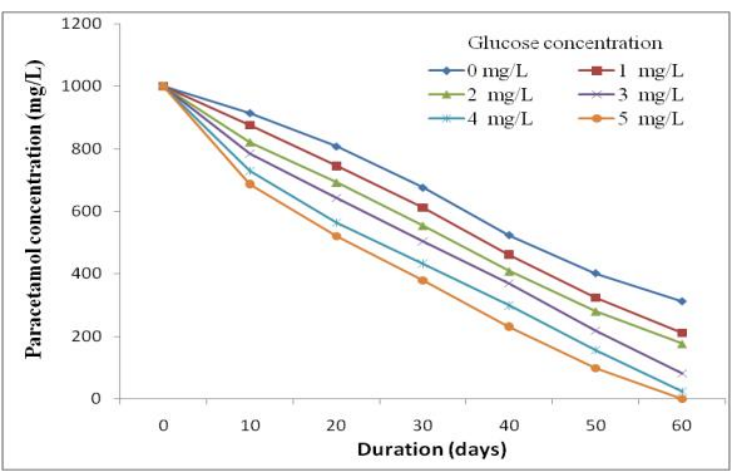

Figure 8: Effect of glucose supplementation to medium on paracetamol biodegradation by $F 2$.

Similarly, Mendonça et al., ${ }^{22}$ reported that $F$. flocciferum was able to reduce the phenolic concentration from $200 \mathrm{mg} / \mathrm{l}$ to below detection limits in $24 \mathrm{~h}$. In addition, it was reported that the Fusarium sp. E033 was able to degrade $65-70 \%$ of benzo(a) pyrene $(100 \mathrm{mg} / \mathrm{l})$ within 30 days of incubation at $32^{\circ} \mathrm{C}^{35}$. Also, it was reported that the $77 \%$ of $20 \mathrm{ppm}$ of bisphenol A was removed by Aspergillus sp. ${ }^{25}$ Another study by Raaman et al., ${ }^{27}$ found that A. japonicus and A. niger degraded $12 \%$ and $8 \%$ of polyethylene, respectively, in 30 days. Also, a study by Hasan ${ }^{36}$ observed that $93 \%$ of the kerosene concentration was degraded by $A$. niger after 28 days of incubation.A study by Govarthanan et al., ${ }^{26}$ reported that Penicillium sp. CHY-2 was able to degrade $34.0 \%$ of decane and $25.0 \%$ of butylbenzene $(500 \mathrm{mg} / \mathrm{l}$ each $)$ at $20^{\circ} \mathrm{C}$ after 28 days. Few studies up to now have been reported about the using of fungi enzymes to degrade the paracetamol. It was combined two fungal enzymes, laccase (Trametes versicolor) and tyrosinase (mushroom), into a cross-linked enzyme aggregate which was used to transform paracetamol from wastewater samples. It was found that more than $80 \%$ of paracetamol present in municipal wastewater and hospital waste water, were transformed by the crosslinked enzymes ${ }^{37}$.

\section{CONCLUSION}

Pharmaceutical wastewater effluent was considered the most potential source to isolate microorganisms able to utilize paracetamol as sole carbon and nitrogen sources. Two fungal species were isolated from the wastewater and identified as $A$. niger and $F$. oxysporium. The isolated were able to survive in the presence of paracetamol concentrations up to 1500 $\mathrm{mg} / \mathrm{l}$. The fungal species identified herein, are reported for the first time as paracetamol degraders. Temperature and $\mathrm{pH}$ influenced the rate of paracetamol degradation. Therefore, this work has provided a useful guideline in estimating potential paracetamol degraders isolated from the environment. An advanced study of the metabolic pathways involved in paracetamol degradation may increase our understanding on the mechanisms involved in the biodegradation process.

\section{ACKNOWLEDGEMENTS}

The authors are thankful to the Yemen Drug Company for Industrial and Commercial (YEDCO) for the facilities provided for the use of HPLC.

\section{AUTHOR'S CONTRIBUTION}

The manuscript was carried out, written, and approved in collaboration with all authors.

\section{CONFLICT OF INTEREST}

No conflict of interest associated with this work.

\section{REFERENCES}

1. Martindale W. The complete drug reference, cough suppressants, expectorants, mucolytics and nasal decongestants, $36^{\text {th }}$ ed. The pharmaceutical Press, London, England 2009; 1082.

2. Sebastine IM, Wakeman RJ. Consumption and environmental hazards of pharmaceutical substances in the UK. Process Saf Environ Prot 2003; 81:229-235.

https://doi.org/10.1205/095758203322299743

3. Zhang X, Wu F, Wu XW, Chen P, Deng N. Photodegradation of acetaminophen in $\mathrm{TiO}_{2}$ suspended solution. J Hazard Mater 2008; 157:300-307.

https://doi.org/10.1016/j.jhazmat.2007.12.098

4. Alajmi HM. Effect of physical, chemical and biological treatment on the removal of five pharmaceuticals from domestic wastewater in laboratory-scale reactors and a fullscale plan. Ph.D. dissertation, University of Newcastle Upon Tyne, England, UK. 2014; 50-87.

https://doi.org/10.1016/j.watres.2005.05.031

5. Edrees WH, Abdullah QY, AL-Kaf A, Naji KM. A review on comparative study between the physicochemical and biological processes for paracetamol degradation. Universal $\mathbf{J}$ Pharm Res 2017; 2:9-13.

https://doi.org/10.22270/ujpr.v2i2.RW4

6. Kleywegt S, Pileggi V, Yang P, Hao C, et al. Pharmaceuticals, hormones and bisphenol $\mathrm{A}$ in untreated source and finished drinking water in Ontario, Canada: Occurrence and treatment efficiency. Sci Total Environ 2011; 409:1481-1488. 
https://doi.org/10.1016/j.scitotenv.2011.01.010

7. Zimmerman MJ. Occurrence of organic wastewater contaminants, pharmaceuticals, and personal care products in selected water supplies. Cape Cod, Massachusetts, June 2004: US, Geological Survey Open-File Report 1206, 2005; 1-16.

8. Lin YA, Tsai T. Occurrence of pharmaceuticals in Taiwan's surface waters: Impact of waste streams from hospitals and pharmaceutical production facilities. Sci Total Environ 2009; 407: 3793-3802.

https://doi.org/10.1016/j.scitotenv.2009.03.009

9. Thomas KV, Dye C, Schlabach M, Langford K. Source to sink tracking of selected human pharmaceuticals from two Oslo city hospitals and a wastewater treatment works. J Environ Monit 2007; 9:1410-1418.https://doi.org/10.1039/B709745J

10. Gomez MJ, Bueno MJM, Lacorte S, Fernandez-Alba AR, Aguera A. Pilot survey monitoring pharmaceuticals and related compounds in a sewage treatment plant located on the Mediterranean coast. Chemosphere 2007; 66: 993-1002 https://doi.org/10.1016/j.chemosphere.2006.07.051

11. Wu S, Zhang L, Chen J. Paracetamol in the environment and its degradation by microorganisms. Appl Microbiol Biotechnol 2012; 96:875-884 https://doi.org/10.1007/s00253-012-4414-4

12. Andreozzi R, Caprio V, Marotta R, Vogna D. Paracetamol oxidation from aqueous solutions by means of ozonation and $\mathrm{H}_{2} \mathrm{O}_{2} / \mathrm{UV}$ system. Water Res 2003; 37: 993-1004 https://doi.org/10.1016/S0043-1354(02)00460-8

13. Yang L, Yu LE, Ray MB. Degradation of paracetamol in aqueous solutions by $\mathrm{TiO}_{2}$ photocatalysis. Water Res 2008; 42:3480-3488. https://doi.org/10.1016/j.watres.2008.04.023

14. Trovo AG, Melo SS, Nogueira RP. Photodegradation of the pharmaceuticals amoxicillin, bezafibrate and paracetamol by the photo-Fenton process: Application to sewage treatment plant effluent. J Photochem Photobiol A 2008; 198: 215-220. https://doi.org/10.1016/j.jphotochem.2008.03.011

15. Husaini A, Roslan HA, Hii KSY, Ang CH. Biodegradation of aliphatic hydrocarbon by indigenous fungi isolated from usedmotor oil contaminated sites. World J Micro Biotech 2008; 24(12): 2789-2797. https://doi.org/10.1007/s11274-0089806-3

16. Hart A, Orr DL. The degradation of paracetamol (4hydroxyacetanilide) and other substituted acetanilides by a Penicillium species. A Van Leeuw 1975; 41:239-247. https://doi.org/10.1007/bf02565059

17. Ahmed S, Javed AM, Tanvir S, Hameed A. Isolation and characterization of a Pseudomonas strain that degrades 4acetamidophenol and 4-aminophenol. Biodegradation 2001; 12: 303-309.https://doi.org/10.1023/a:1014395227133

18. Moubasher AH. Soil fungi of Qatar and Other Arab Countries. The scientific and applied research centre, University of Qatar, Doha, Qatar. 1993.

19. Khan AS, Hamayun M, Ahmed S. Degradation of 4aminophenol by newly isolated Pseudomonas sp. strain ST-4. Enzyme Microb Tech 2006; 38:10-13. https://doi.org/10.1016/j.enzmictec.2004.08.045

20. Khan SA, Hamayun M, Khan AL, Ahmad B, Ahmed S, Lee J. Influence of $\mathrm{pH}$, temperature and glucose on biodegradation of 4-aminophenol by a novel bacterial strain, Pseudomonas sp. ST-4. African J Biotech 2008; 8(16): 3827-3831.

21. United States Pharmacopoeia (USP), 30-NF/25. Monograph: Paracetamol (acetaminophen). The United States Pharmacopeial Convention, Rockville, USA 2005; 30(5):172174.

22. Mendonça E, Martins A, Anselmo AM. 2004. Biodegradation of natural phenolic compounds as single and mixed substrates by Fusarium flocciferum. Electronic J Biotech 2004; 7(1): 3037.https://doi.org/10.2225/vol7-issue1-fulltext-3
23. Asgher M, Bhatti HN, Ashraf M, Legge RL. Recent developments in biodegradation of industrial pollutants by white rot fungi and their enzyme system. Biodegradation 2008; 19:771-783.https://doi.org/10.1007/s10532-008-9185-3

24. Kues U. Fungal enzymes for environmental management. Curr Opin Biotech 2015; 33:268-278. https://doi.org/10.1016/j.copbio.2015.03.006

25. Kamaraj M, Manjudevi M, Sivaraj R. Degradation of bisphenol a by Aspergillus sp. isolated from tannery industry effluent. Int J of Pharm Life Sci 2012; 3(4): 1585-1589.

26. Govarthanan M, Fuzisawa S, Hosogai T,Chang Y-C. Biodegradation of aliphatic and aromatic hydrocarbons using the filamentous fungus Penicillium sp. $\mathrm{CHY}-2$ and characterization of its manganese peroxidase activity. RSC Adv 2017; 7: 20716-20723. https://doi.org/10.1039/C6RA28687A

27. Raaman N, Rajitha N, Jayshree A, Jegadeesh R. Biodegradation of plastic by Aspergillus spp. isolated from polythene polluted sites around Chennai.J Acad Indus Res 2012; 1(6): 313-316.

28. Marinho G, Rodrigues K, Araujo R, Pinheiro ZB, Silva GM. Glucose effect on degradation kinetics of methyl parathion by filamentous fungi species Aspergilus niger AN400. Eng Sanit Ambient 2011; 16(3): 225-230. https://doi.org/10.1590/S1413-41522011000300004

29. Yemendzhiev H, Gerginova M, Zlateva P, Stoilova I, Krastanov A, Alexieva Z. Phenol and cresol mixture degradation by Aspergillusa wamori strain: Biochemical and kinetic substrate interactions. Proceedings of ECO pole 2008; 2(1):153-159.

30. Launen L, Pinto L, Moore M. Optimization of pyrene oxidation by fungi using response surface analysis. Appl Microbiol Biotech 1999; 51: 510-515. https://doi.org/10.1007/s002530051425

31. Verdin A, Sahraoui AL-H, Newsam R, Robinson G, Durand R. Polycyclic aromatic hydrocarbons storage by Fusariumsolani in intracellular lipid vesicles. Environmental Pollution 2005; 133:283-291.

https://doi.org/10.1016/j.envpol.2004.05.040

32. Marinho G, Barbosa BA, Rodrigues K, Aquino M, Pereira L.Potential of the filamentous fungus Aspergillus niger AN 400 to degrade Atrazine in wastewaters. Biocat Agri Biotech 2017; 9:162-167.https://doi.org/10.1016/j.bcab.2016.12.013

33. Singh H. Mycoremediation: Fungal Bioremediation. John Wiley and Sons, Inc., Hoboken, New Jersey, Canada. 2006; 38.

34. Cruz-Morató C, Lucas, D, Llorca M, Gorga M, RodríguezMozaz S, Barceló D, Marco-Urrea E, Sarrà M, Vicent T. Hospital wastewater treatment by fungal bioreactor: Removal efficiency for pharmaceuticals and endocrine disruptor chemicals. Sci Total Environ 2014; 493:365-376. https://doi.org/10.1016/j.scitotenv.2014.05.117

35. Chulalaksananukul S, Gadd GM, Sangvanich P, Sihanonth P, Piapukiew J, Vangnai AS. Biodegradation of benzo(a) pyrene bya newly isolated Fusarium sp. Federation of European Microbiological Societies (FEMS Microbiol Lett) 2006; 262: 99-106.

36. Hasan IF. Biodegradation of Kerosene by Aspergillus niger and Rhizopus stolinifer. J App EnvirMicro 2014; 2(1): 31-36.

37. Ba S, Haroune L, Cruz-Morató C, Jacquet C, Touahar IE, Bellenger J, Legault YC, Jones JP, Cabana H. Synthesis and characterization of combined cross-linked laccase and tyrosinase aggregates transforming acetaminophen as a model phenolic compound in wastewaters. Sci Total Environ 2014; 487:748-755.https://doi.org/10.1016/j.scitotenv.2013.10.004 